\title{
Analisa Perbandingan Performansi Hot Standby Router Protocol (HSRP) dengan Gateway Load Balancing Protocol (GLBP) Pada Router Spoke DMVPN
}

\author{
Michelle Claudia, Muhammad Rifqi* \\ Fakultas Ilmu Komputer, Teknik Informatika, Universitas Mercu Buana, Jakarta, Indonesia \\ Email: ${ }^{4} 41516120006 @$ student.mercubuana.ac.id, ${ }^{2,}{ }^{*}$ m.rifqi@mercubuana.ac.id \\ Email Penulis Korespondensi: m.rifqi@mercubuana.ac.id
}

\begin{abstract}
Abstrak-Pemanfaatan koneksi internet untuk membangun jalur Virtual Private Network (VPN) pada perusahaan sudah banyak digunakan. Seperti penggunaan teknologi Dynamic Multipoint VPN (DMVPN) dari Cisco, yang dapat menghubungkan Spoke atau kantor cabang, dengan HUB atau data center. Selain membutuhkan jaringan yang aman, perusahaan juga memerlukan ketersediaan jaringan yang tinggi. Salah satunya dengan menggunakan metode redundansi agar dapat meminimalisir downtime saat terjadi kerusakan perangkat. Pada penelitian ini router spoke akan menggunakan 2 metode redundansi milik Cisco, yaitu yaitu Hot Standby Router Protocol (HSRP) dan Gateway Load Balancing Protocol (GLBP). Penelitian bertujuan untuk membandingkan perfomansi QoS dan downtime diantara kedua protokol tersebut sehingga menemukan metode yang sesuai untuk jaringan DMVPN pada kantor cabang. Skenario pengujian dilakukan pada simulator GNS-3 dengan menggunakan layanan File Transfer Protocol (FTP). Hasil pengujian yang didapatkan nilai throughput HSRP lebih kecil dengan selisih 0,20\% dari GLBP, kenaikan delay rata-rata pada HSRP lebih kecil dengan selisih 1,07\% dari GLBP, waktu transfer data pada HSRP lebih cepat dengan selisih 1,49\% dibanding GLBP, dan downtime yang terjadi pada HSRP lebih cepat 4,13\% dari GLBP. Sehingga kesimpulan yang didapatkan metode HSRP merupakan solusi redundansi yang sesuai pada router spoke.
\end{abstract}

Kata Kunci: Performansi; HSRP; GLBP; Redundansi; Simulasi

\begin{abstract}
The use of internet connections to develop Virtual Private Network (VPN) lines in companies has been massively applied. An example is the use of Dynamic Multipoint VPN (DMVPN) technology from Cisco, which can connect Spoke or branch offices through HUB or data centers. Besides requiring a secure network, companies also need high network availability. One of them is by using the redundancy method in order to minimize downtime when device damage occurs. In this research, the spoke router will apply two redundancy methods by Cisco, which are Hot Standby Router Protocol (HSRP) and Gateway Load Balancing (GLBP). This research aims to compare the QoS performances and downtime between the two protocols in order to discover the suitable method for DMVPN networks at branch offices. The test scenario is conducted on the GNS-3 simulator using the File Trasnfer Protocol (FTP) service. The obtained test result shows that the HSRP throughput value is smaller from the GLBP with a difference of $0.20 \%$, the increase in the average delay of the HSRP is smaller from the GLBP with a difference of $1.07 \%$. The HSRP data transfer time is faster than GLBP with a difference of $1.49 \%$, and HSRP downtime is $4.13 \%$ faster than GLBP. The conclusion is that a suitable redundancy solution for spoke router using the HSRP method.
\end{abstract}

Keywords: Performance; HSRP; GLBP; Redundancy; Simulation

\section{PENDAHULUAN}

Saat ini banyak perusahaan yang memanfaatkan teknologi informasi dalam menjalankan proses bisnisnya, terutama dengan menggunakan internet untuk membuat jaringan komputer agar perangkat dapat saling berkomunikasi dan berbagi data. Jaringan komputer yang dibutuhkan adalah jaringan yang bersifat aman dan memiliki ketersediaan yang tinggi. Untuk membangun jaringan yang aman, perusahaan yang memiliki banyak cabang sering menggunakan VPN (Virtual Private Network). Namun, penggunaan VPN tradisional ini mempunyai harga operasional dan pemeliharaan yang tinggi. Sebagai solusi, Cisco mempunyai tekonologi DMVPN (Dynamic Multipoint $V P N)$.

DMVPN merupakan sebuah protokol yang menawarkan komunikasi VPN yang aman untuk komunikasi antar cabang perusahaan. Arsitektur DMVPN terdiri dari implementasi jaringan Hub dan Spoke. Hub merupakan perwakilan node pusat jaringan, sedangkan Spoke adalah node yang berada pada remote location atau biasanya kantor cabang. DMVPN membangun sebuah site-to-site tunnel dengan memanfaatkan koneksi internet publik[1]. Teknologi ini dapat digunakan pada perusahaan yang sering mengalami penambahan atau pengurangan jumlah cabang. Hal ini karena perangkat yang sudah dikonfigurasi tidak perlu dilakukan konfigurasi kembali[2]. Sehingga mengurangi kompleksitas pada sisi konfigurasi perangkat, meningkatkan fleksibilitas dan menjaga harga operasional serta pemeliharan tetap rendah.

Dalam melakukan perancangan jaringan selain faktor keamanan, perusahaan juga menuntut terjaminnya jaringan yang terus-menerus tersedia. Hal ini bertujuan untuk menjaga proses bisnis yang sedang berjalan. Penggunaan metode redundansi pada perangkat merupakan salah satu cara untuk membuat sistem dengan ketersediaan yang tinggi. Redundansi jaringan komputer merupakan proses instalasi perangkat alternatif atau tambahan untuk mempertahankan fungsi jaringan, ketika terjadi kerusakan pada perangkat utama. Adapun protokol yang dapat melakukan redundansi pada jaringan komputer yaitu FHRP (Fast Hop Redundancy Protocol). FHRP terdiri dari berbagai macam jenis, 3 jenis yang utama sering digunakan adalah HSRP (Hot Standby Router Protocol), GLBP (Gateway Load Balancing Protocol), dan VRRP (Virtual Router Redundancy Protocol). HSRP 
dan GLBP merupakan milik Cisco atau Cisco proprietary sedangkan VRRP adalah standar IETF (RFC 3768)[3]. HSRP menyediakan redundansi dengan membuat satu router aktif dan lainnya sebagai standby, sedangkan GLBP dapat membuat semua router dalam keadaan aktif dan memiliki fitur load balancing.

PT XYZ merupakan sebuah perusahaan pembiayaan yang sudah memiliki lebih dari 100 kantor cabang di Indonesia. Perusahaan ini sudah menggunakan jaringan berbasis DMVPN sebagai penghubung antara kantor cabang dengan kantor pusat. Jaringan pada cabang digunakan untuk mendukung proses bisnis seperti akses layanan email, web hingga aplikasi internal. Kondisi yang terjadi pada PT XYZ hanya memiliki satu router spoke yang aktif disetiap cabang. Satu router spoke lainnya berada dalam kondisi mati. Hal ini memungkinkan terjadinya perbedaan konfigurasi antara router spoke cadangan yang mati dengan spoke utama, terlebih jika sudah banyak perubahan yang terjadi. Karena kondisi tersebut, jaringan cabang memiliki resiko terjadinya downtime yang lebih lama apabila router mengalami kerusakan atau mati.

Cisco memiliki metode yang dapat digunakan sebagai solusi redundansi dan mengurangi downtime, yaitu HSRP dan GLBP. Pemilihan kedua metode tersebut dikarenakan perangkat yang digunakan saat ini merupakan router Cisco, sehingga akan lebih maksimal jika menggunakan protokol milik Cisco sendiri. Jaringan cabang PT XYZ akan dirancang menggunakan kedua metode redundansi ini dengan kondisi dua router spoke yang aktif. Perancangan dilakukan berdasarkan keadaaan jaringan pada cabang PT XYZ saat ini.

Terdapat beberapa penelitian yang membandingkan metode redundansi tersebut antara lain adalah [4]. Penelitian yang dilakukan mendapatkan hasil metode GLBP merupakan rekomendasi metode terbaik untuk mengatasi kegagalan jaringan, berdasarkan hasil pengujian performansi jaringan TCP/IP. Penelitan [5] dilakukan pada jaringan yang menggunakan routing protocol EIGRP (Enhanced Interior Gateway Routing Protocol) mendapatkan kinerja HSRP lebih baik dari GLBP pada layanan video streaming. Penelitian [6] memberikan hasil kinerja VRRP pada topologi Star dengan routing EIGRP lebih baik dibanding HSRP dan GLBP karena hasil delay tidak mengalami kenaikan saat kondisi jaringan terputus. Hasil tersebut dikarenakan protokol VRRP mengirimkan pesan hello setiap 1 detik, sedangkan protokol GLBP dan HSRP setiap 3 detik. Maka pada penelitian ini konfigurasi hello pada HSRP dan GLBP akan diubah menjadi 1 detik agar mendapatkan hasil yang maksimal seperti protokol VRRP pada penelitian [6].

Berdasarkan penelitian [4],[5],[6] setiap metode redundansi memiliki kelebihan dan kelemahan tersendiri. Maka penelitian ini akan membandingkan kinerja dari kedua metode redundasi milik Cisco pada jaringan DMVPN. Pengukuran kinerja yang akan dilakukan menggunakan parameter QoS (Quality of Services) yaitu throughput dan delay. Selain parameter QoS, penelitian ini juga akan menguji nilai transfer time dan lamanya downtime pada setiap metode. Sehingga hasil penelitian ini dapat memberikan solusi metode redundansi yang sesuai untuk router spoke.

\section{METODOLOGI PENELITIAN}

\subsection{HSRP}

Hot Standby Router Protocol (HSRP) merupakan protokol standar gateway dari Cisco yang berfungsi untuk menyediakan redundansi pada jaringan. HSRP akan membuat sebuah virtual router yang bertugas sebagai gateway. Seluruh transimi data akan melewati active gateway. Active Gateway dipilih berdasarkan prioritas tertinggi atau router dengan IP Address tertinggi. Pada HSRP konfigurasi default untuk prioritas adalah 100, interval waktu pengiriman paket "Hello" adalah 3 detik, dan interval waktu menunggu paket "Hello" adalah 10 detik. Jika active router tidak membawa paket "Hello" selama 10 detik, maka standby router dengan prioritas tertinggi selanjutnya akan mengambil alih dan menjadi active router. [7]

\subsection{GLBP}

Gateway Load Balancing Protocol (GLBP) merupakan protokol standar milik Cisco yang mendukung fungsi load balancing. Dalam GLBP terdapat dua peran dari gateway, yaitu Active Virtual Gateway (AVG) dan Active Virtual Forwarder (AVF). Gateway yang memiliki prioritas tertinggi akan menjadi AVG, yang bertugas melakukan reply terhadap paket Address Resolution Protocol (ARP). Router yang lainnya akan bertindak sebagai backup untuk AVG. Konfigurasi default untuk interval pengiriman paket "Hello" dan waktu tunggu pada GLBP sama seperti konfigurasi default pada HSRP. [7]

\subsection{QoS (Quality of Services)}

Parameter QoS yang digunakan pada penelitian ini, yaitu :

a. Throughput [8]

Throughput merupakan ukuran untuk mengetahui seberapa cepat sebenarnya data dapat terkirim pada jaringan. Rumus perhitungan throughput :

Throughput $=\frac{\text { jumlah data yang dikirim }}{\text { waktu pengiriman data }}$ 


\section{JURNAL MEDIA INFORMATIKA BUDIDARMA}

Volume 5, Nomor 2, April 2021, Page 504-512

ISSN 2614-5278 (media cetak), ISSN 2548-8368 (media online)

Available Online at https://ejurnal.stmik-budidarma.ac.id/index.php/mib

DOI 10.30865/mib.v5i2.2846

b. Delay [8]

Delay merupakan rata-rata waktu yang diperlukan untuk melakukan transmit data dari pengirim ke penerima.

Rumus perhitungan end-to-end delay:

Delay $=\frac{\text { waktu pengiriman paket }}{\text { total paket diterima }}$

\subsection{Metode Pengumpulan Data}

Metode pengumpulan data yang digunakan dalam penelitian ini adalah observasi dan studi pustaka. Peneliti melakukan pengamatan pada jaringan di PT XYZ yang akan dijadikan penelitian agar dapat memperoleh datadata yang dibutuhkan untuk dilakukan analisa dan simulasi. Peneliti juga melakukan pengumpulan data dari berbagai referensi seperti jurnal, e-book, buku atau laporan yang berkaitan dengan penelitian.

\subsection{Tahapan Penelitian}

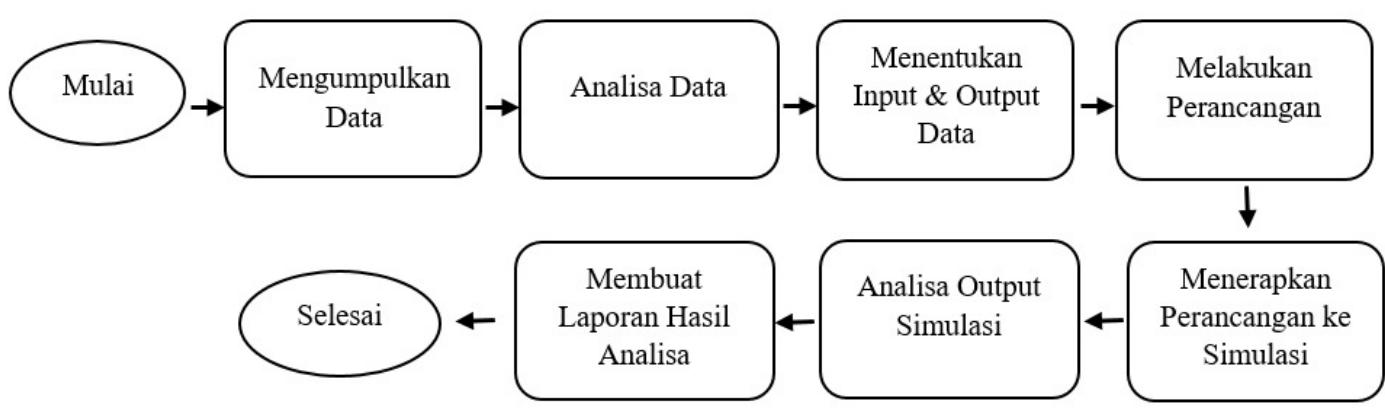

Gambar 1. Alur Tahapan Penelitian

Berikut tahapan-tahapan pada penelitian ini:

a. Mengumpulkan Data

Melakukan observasi terhadap keadaan jaringan yang sedang berjalan dan mengumpulkan data yang dibutuhkan seperti topologi jaringan, jenis perangkat yang digunakan dan beban jaringan yang dilewati router spoke.

b. Analisa Data terkait Penelitian

jaringan. Hasil yang didapatkan adalah setiap cabang mempunyai 2 (dua) router cisco, tetapi hanya terdapat 1 (satu) router spoke yang aktif. Bandwidth pada kantor cabang dipakai untuk mengakses layanan email, web dan aplikasi internal perusahaan. Aktifitas yang paling sering dilakukan adalah download file dari web internal perusahaan, dengan format file .pdf.

c. Menentukan input dan output data

Parameter input ditetapkan berdasarkan hasil analisa data pada tahap sebelumnya. Berikut peralatan yang akan digunakan dalam penelitian untuk membuat simulasi jaringan :

Tabel 1. Kebutuhan Peralatan Simulasi

\begin{tabular}{ccc}
\hline Kategori & Spesifikasi & Fungsi \\
\hline Hardware & Laptop HP & \\
& Intel Core i7 & \\
& Windows 10 & \\
Software & GNS3 & Aplikasi simulasi jaringan \\
& Wireshark & Aplikasi analisis protokol jaringan \\
& VirtualBox & Aplikasi Virtual Machine \\
\hline
\end{tabular}

Parameter output yang digunakan adalah parameter QoS (throughput dan delay), waktu transfer file dan downtime.

d. Melakukan Perancangan

Membuat rancangan jaringan menggunakan metode redundansi dan rancangan skenario yang nanti akan digunakan untuk uji coba.

e. Menerapkan Perancangan ke Simulasi

Mensimulasikan rancangan jaringan menggunakan aplikasi GNS3 dan melakukan skenario uji coba terhadap metode HSRP dan GLBP yang digunakan pada router spoke.

f. Analisa Output Simulasi

Setelah skenario uji coba sudah selesai dilakukan peneliti menganalisa parameter output.

g. Membuat Laporan Hasil Analisa 
JURNAL MEDIA INFORMATIKA BUDIDARMA

Volume 5, Nomor 2, April 2021, Page 504-512

ISSN 2614-5278 (media cetak), ISSN 2548-8368 (media online)

Available Online at https://ejurnal.stmik-budidarma.ac.id/index.php/mib

DOI 10.30865/mib.v5i2.2846

Tahap terakhir adalah memberikan hasil analisa performansi dari uji coba kedua metode redundansi pada router spoke DMVPN.

\subsection{Perancangan Jaringan}

Gambar 2 merupakan topologi yang akan digunakan dalam simulasi berdasarkan keadaan jaringan yang sedang berjalan.

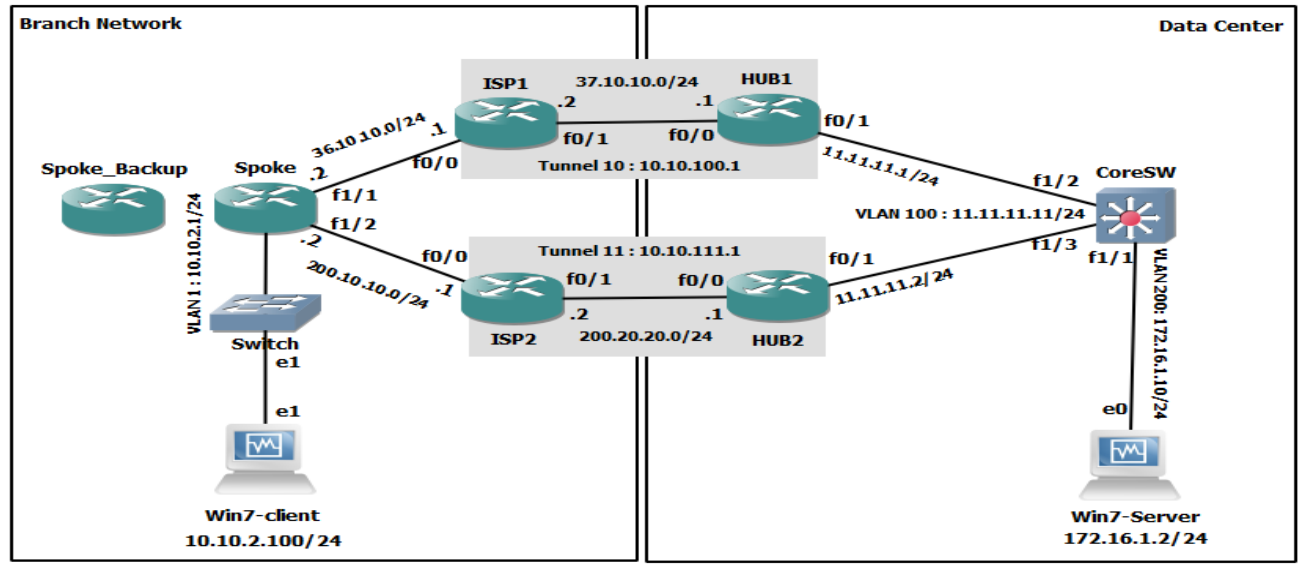

Gambar 2. Topologi Jaringan Existing

Adapun peralatan yang diperlukan untuk menjalankan simulasi jaringan pada GNS-3, sebagai berikut :

a. 6 unit router yang akan digunakan sebagai :

1. Spoke sebanyak 2 unit

2. Modem sebanyak 2 unit

3. HUB sebanyak 2 unit

b. 1 unit switch layer 2

c. 1 unit switch layer 3

d. 3 unit PC yang akan digunakan sebagai Client dan Server

Pada penelitian ini kedua router spoke akan diaktifkan menggunakan protokol redundansi HSRP atau GLBP. Router spoke akan saling terhubung melalui perangkat switch tambahan. Port pada switch yang mengarah ke router spoke akan menggunakan mode trunk, dan port yang mengarah ke switch access dan modem ISP akan menggunakan mode vlan access. Topologi perancangan dengan metode redundansi dapat dilihat pada Gambar 3.

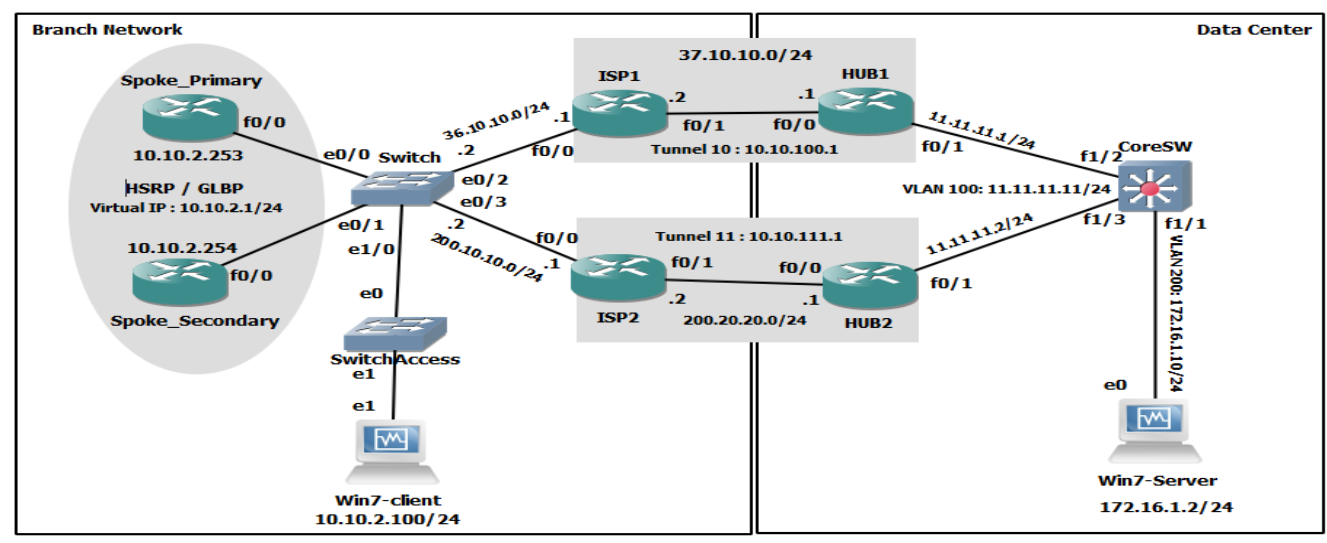

Gambar 3. Perancangan Jaringan Dengan Metode Redundansi

Dalam keadaan normal PC client akan mengakses ke server melalui spoke primary, tetapi jika spoke primary bermasalah spoke secondary akan mengambil alih. Dengan metode redundansi ini diharapkan dapat meningkatkan ketersediaan jaringan.

\subsection{Skenario Pengujian}

Terdapat 5 skenario yang akan dilakukan pada penelitian ini untuk mendapatkan hasil perbandingan performansi. Skenario pertama dilakukan pengujian pada jaringan exisiting. Skenario kedua dan ketiga dilakukan pengujian pada jaringan dengan metode HSRP. Skenario keempat dan kelima dilakukan pengujian pada jaringan dengan metode GLBP. Pada skenario ketiga dan kelima akan dilakukan simulasi hardware failure, bertujuan untuk 
JURNAL MEDIA INFORMATIKA BUDIDARMA

Volume 5, Nomor 2, April 2021, Page 504-512

ISSN 2614-5278 (media cetak), ISSN 2548-8368 (media online)

Available Online at https://ejurnal.stmik-budidarma.ac.id/index.php/mib

DOI 10.30865/mib.v5i2.2846

memberikan hasil nilai downtime dari masing-masing metode. Semua skenario akan diuji menggunakan layanan FTP, dimana client akan melakukan download file dengan format file .pdf sebesar 5MB dari server. Pengujian dilakukan sebanyak sepuluh kali untuk setiap skenario.

\section{HASIL DAN PEMBAHASAN}

\subsection{Konfigurasi HSRP}

Spoke primary dikonfigurasi dengan priority 110, agar menjadi active router. Sedangkan spoke secondary menggunakan default priory, agar menjadi standby router. Konfigurasi dapat dilihat pada Gambar 4 dan Gambar 5 .

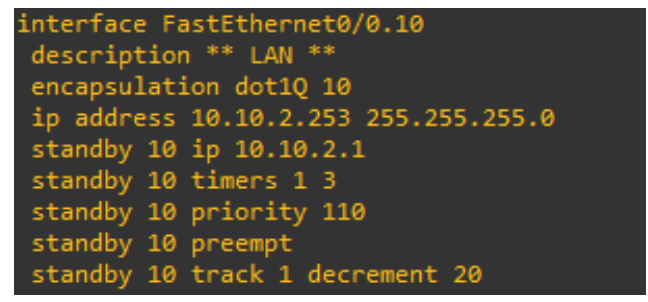

Gambar 4. Konfigurasi HSRP Spoke Primary

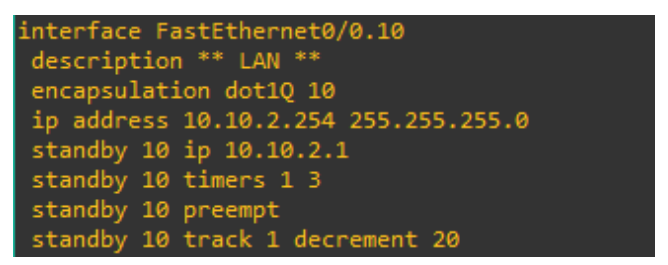

Gambar 5. Konfigurasi HSRP Spoke Secondary

Konfigurasi hello diubah menjadi setiap 1 detik dan hold setiap 3 detik pada semua router. Setiap router juga dikonfigurasikan dengan IP SLA untuk melakukan tracking, tracking dilakukan untuk mengaktifkan fitur Embedded Event Manager (EEM) pada router. EEM bertugas untuk menjalankan otomasi konfigurasi pada port disetiap router. Konfigurasi EEM ditunjukkan pada Gambar 6.

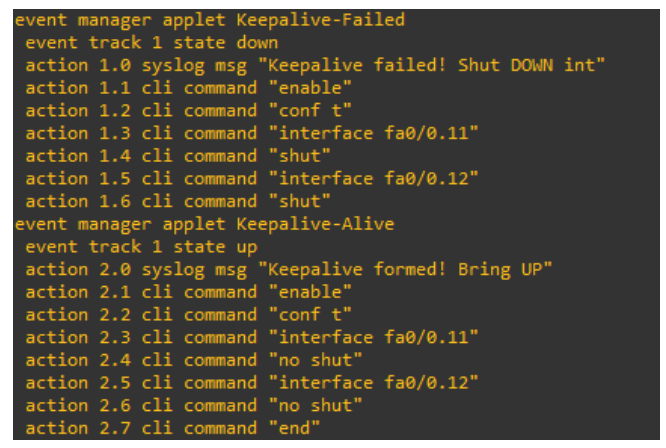

Gambar 6. Konfigurasi EEM

\subsection{Konfigurasi GLBP}

Spoke primary dikonfigurasi dengan priority 110, agar menjadi Active Virtual Gateway (AVG). Sedangakan spoke secondary menggunakan default priority, agar menjadi Active Virtual Forwarder (AVF). Konfigurasi dapat dilihat pada Gambar 7 dan Gambar 8.

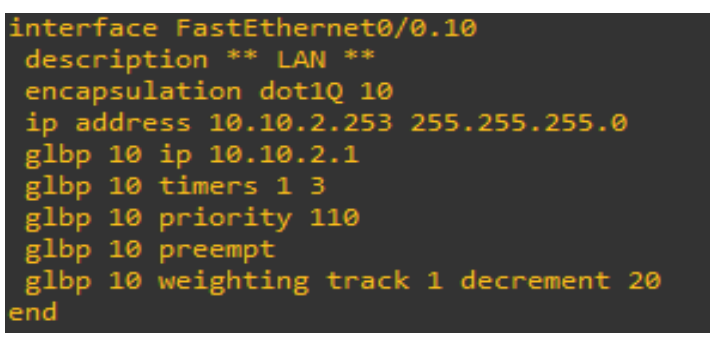

Gambar 7. Konfigurasi GLBP Spoke Primary 
JURNAL MEDIA INFORMATIKA BUDIDARMA

Volume 5, Nomor 2, April 2021, Page 504-512

ISSN 2614-5278 (media cetak), ISSN 2548-8368 (media online)

Available Online at https://ejurnal.stmik-budidarma.ac.id/index.php/mib

DOI 10.30865/mib.v5i2.2846

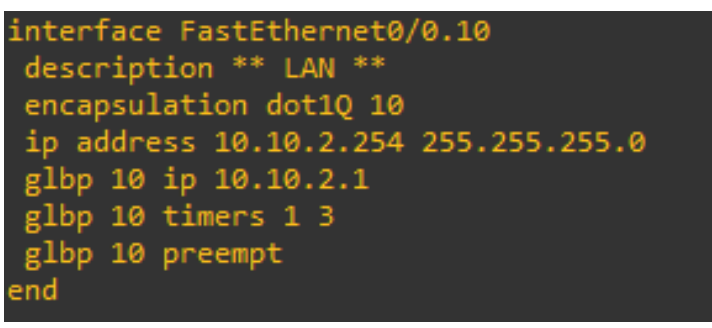

Gambar 8 Konfigurasi GLBP Spoke Secondary

\subsection{Pengujian Sistem}

Sebelum dilakukan pengujian sistem dengan metode redundansi yang sudah dikonfigurasi pada router, perlu dipastikan bahwa jaringan sudah saling terhubung dengan melakukan ping dan trace route dari client ke server. Gambar 9 dan Gambar 10 menunjukkan hasil ping berhasil dan trace route dari client ke server melewati spoke primary pada jaringan dengan metode HSRP

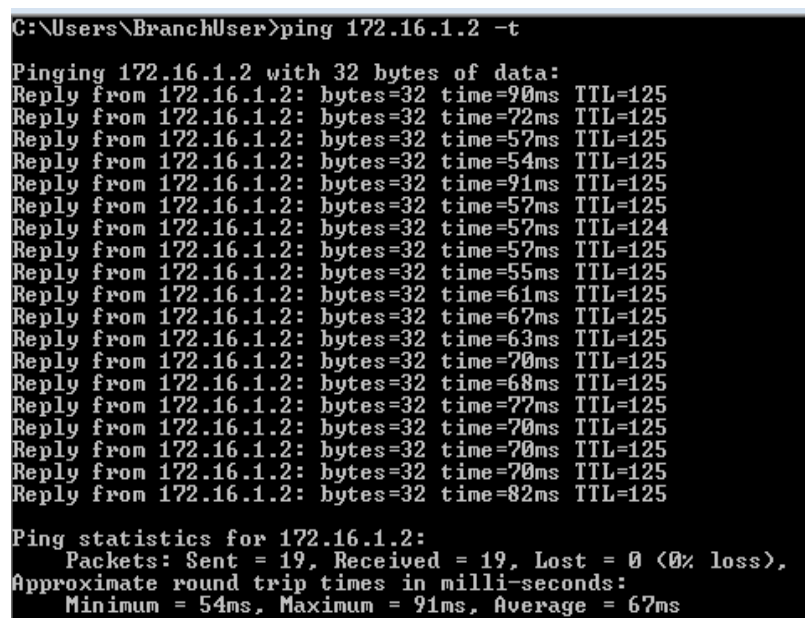

Gambar 9. Test Ping PC Client ke Server

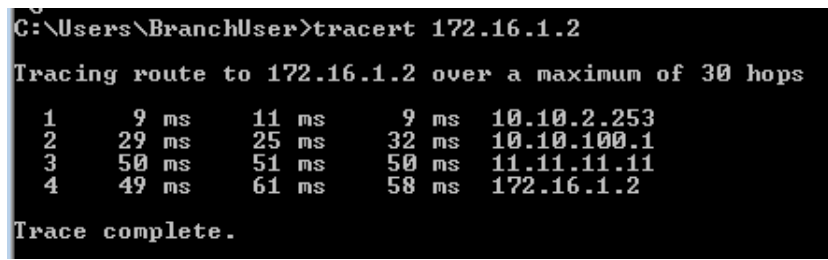

Gambar 10. Traceroute PC Client ke Server

Gambar 10 dan Gambar 11 menunjukkan hasil ping berhasil dan trace route dari client ke server melewati spoke primary pada jaringan dengan metode GLBP.

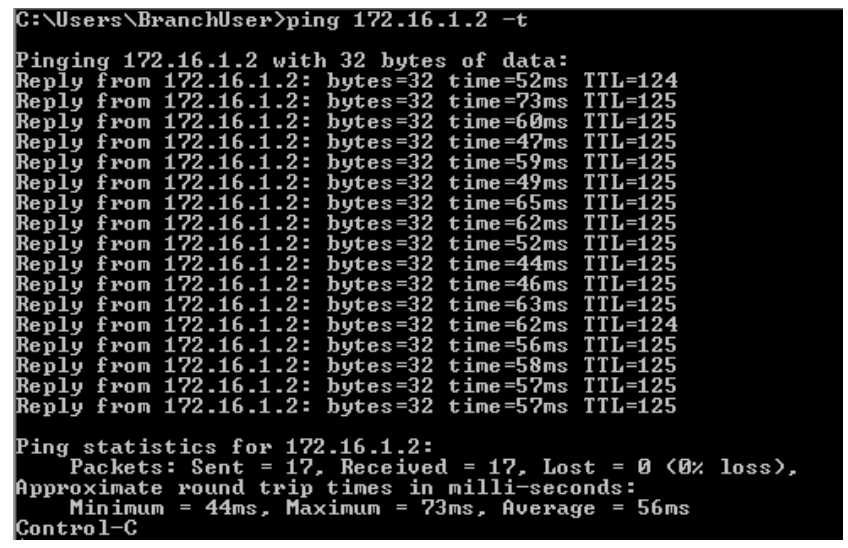

Gambar 11. Test Ping PC Client ke Server 
ISSN 2614-5278 (media cetak), ISSN 2548-8368 (media online)

Available Online at https://ejurnal.stmik-budidarma.ac.id/index.php/mib DOI 10.30865/mib.v5i2.2846

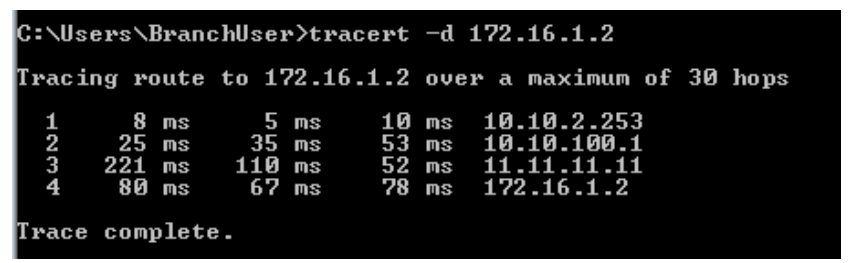

Gambar 12. Traceroute PC Client ke Server

\subsection{Pengujian dan Hasil Parameter Throughput}

Hasil pengujian throughput pada setiap skenario ditampilkan pada Gambar 13.

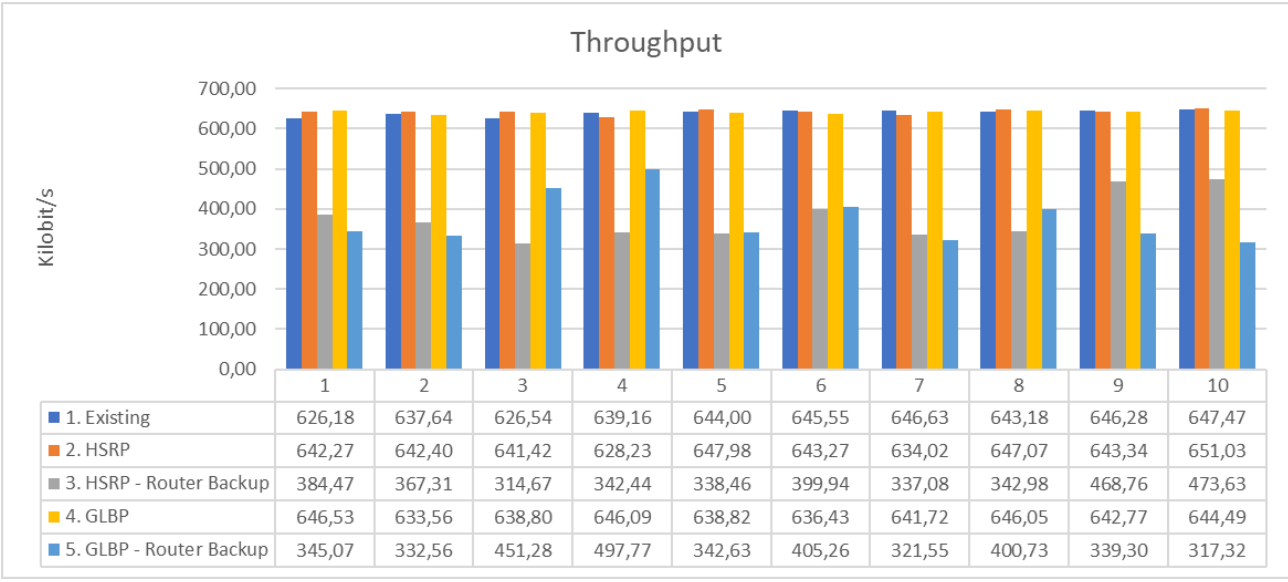

Gambar 13. Grafik Hasil Pengujian Parameter Throughput

Terjadi penurunan throughput pada skenario 3 dan 5 ketika jalur kearah router spoke primary dimatikan. Penurunan throughput yang terjadi pada HSRP antara skenario 2 dan 3 rata-rata sebesar 41,29\%. Sedangkan pada GLBP antara skenario 4 dan 5 terjadi penurunan rata-rata sebesar 41,49\%. Maka penurunan throughput pada HSRP lebih kecil dibanding pada GLBP dengan selisih 1,05Kbit/s atau 0,20\%. Berdasarkan grafik hasil pengujian HSRP lebih stabil dibanding GLBP. Dan metode HSRP menghasilkan rata-rata throughput yang lebih tinggi saat keadaan normal maupun keadaan menggunakan backup router, dibandingkan jaringan existing maupun jaringan dengan metode GLBP. Sehingga, HSRP memiliki nilai parameter throughput yang lebih baik dari GLBP.

\subsection{Pengujian dan Hasil Parameter Delay}

Hasil pengujian delay pada setiap skenario ditampilkan pada Gambar 14.

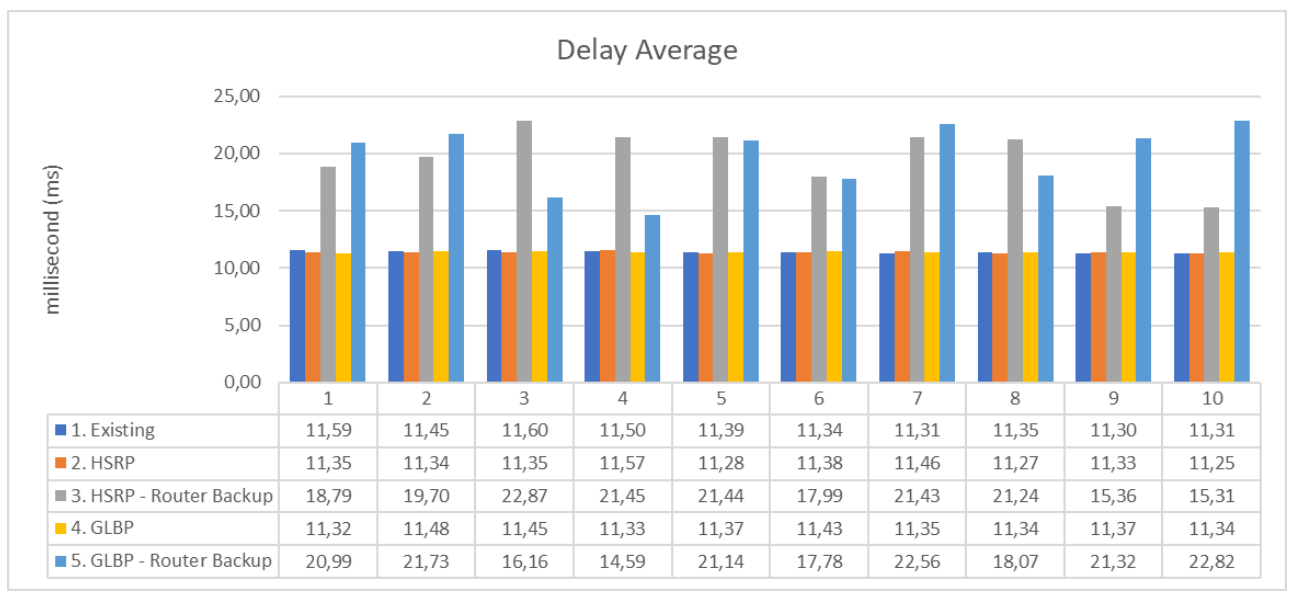

Gambar 14 Grafik Hasil Pengujian Parameter Delay

Terjadi kenaikan delay pada skenario 3 dan 5 ketika jalur kearah router spoke primary dimatikan. Kenaikan delay rata-rata pada HSRP antara skenario 2 dan 3 adalah 8,2 ms atau sebesar 72,2\%. Sedangkan kenaikan delay pada GLBP antara skenario 4 dan 5 adalah 8,3 ms atau sebesar 73,27\%. Maka kenaikan delay rata-rata pada HSRP lebih kecil dibanding pada GLBP dengan selisih 0,13 ms atau 1,07\%. Dan secara keseluruhan nilai delay pada jaringan metode HSRP lebih kecil dibandingkan jaringan exisiting maupun jaringan dengan metode GLBP. Sehingga, HSRP memiliki nilai parameter delay yang lebih baik dari GLBP. 
JURNAL MEDIA INFORMATIKA BUDIDARMA

Volume 5, Nomor 2, April 2021, Page 504-512

ISSN 2614-5278 (media cetak), ISSN 2548-8368 (media online)

Available Online at https://ejurnal.stmik-budidarma.ac.id/index.php/mib

DOI 10.30865/mib.v5i2.2846

\subsection{Pengujian dan Hasil Parameter Transfer Time}

Hasil pengujian transfer time pada setiap skenario ditampilkan pada Gambar 15.

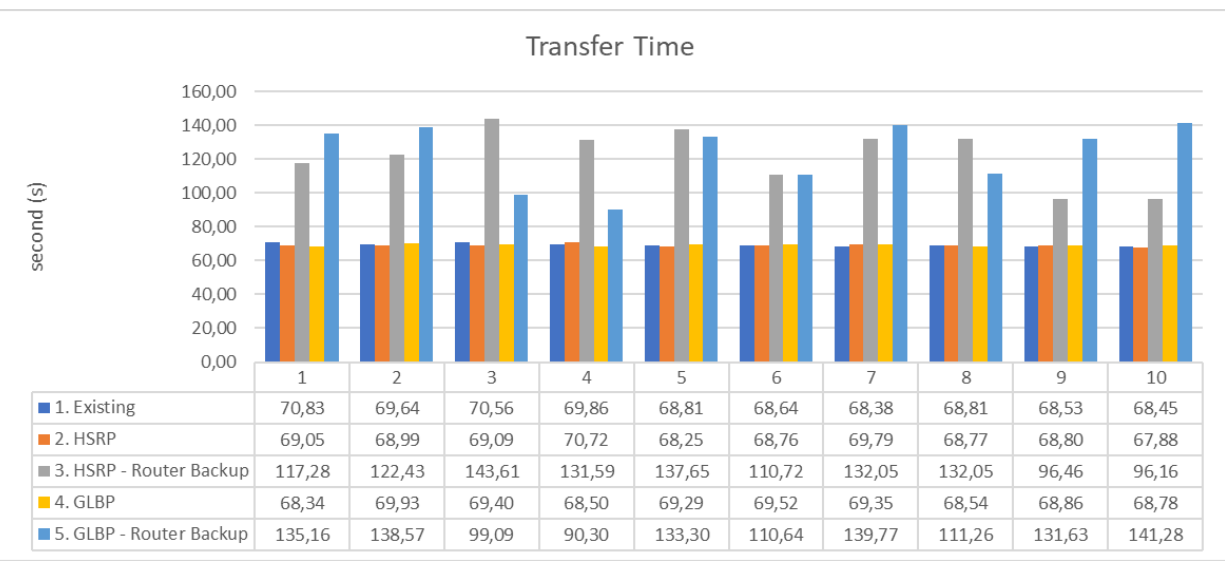

Gambar 15 Grafik Hasil Pengujian Parameter Transfer Time

Terjadi kenaikan waktu transfer data dari server ke client pada skenario 3 dan 5, ketika jalur kearah router spoke primary dimatikan. Rata-rata waktu transfer pada skenario 3 dengan jaringan HSRP mengalami kenaikan sebesar 53 detik atau sebesar 76,79\% dibanding hasil skenario 2. Sedangkan rata-rata waktu transfer pada skenario 5 dengan jaringan GLBP mengalami kenaikan sebesar 54 detik atau sebesar 78,28\% dibanding hasil skenario 4. Maka kenaikan waktu tranfer data pada HSRP masih lebih kecil dibanding pada GLBP dengan selisih 1,06 detik atau $1,49 \%$. Secara keseluruhan nilai waktu transfer pada jaringan metode HSRP juga lebih kecil dibandingkan jaringan exisiting maupun jaringan dengan metode GLBP. Sehingga, HSRP memiliki nilai parameter transfer time yang lebih baik dari GLBP.

\subsection{Pengujian dan Hasil Parameter Downtime}

Hasil pengujian downtime pada setiap skenario ditampilkan pada Gambar 16.

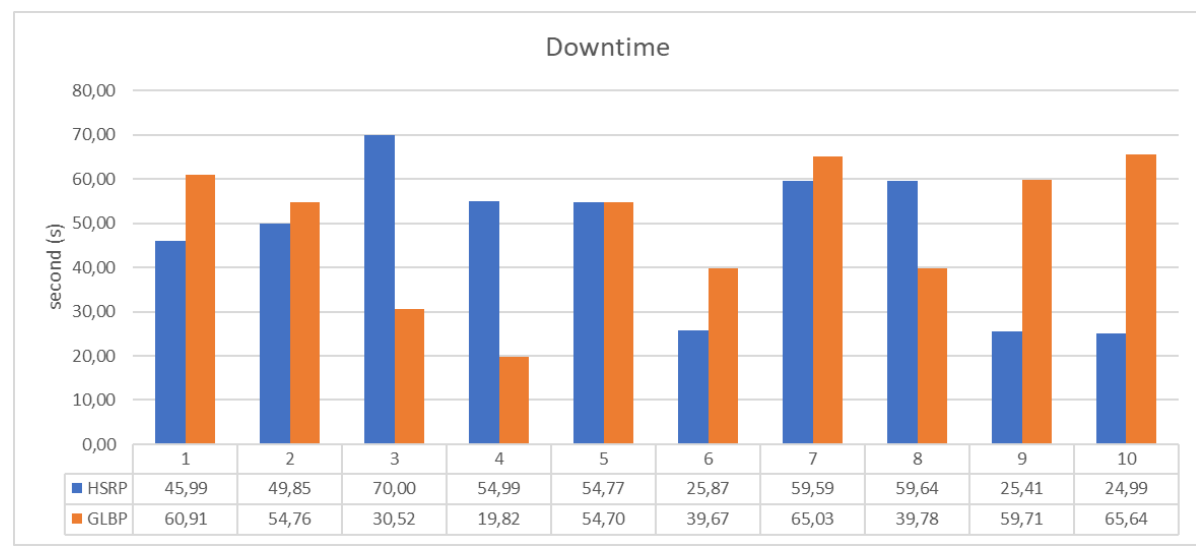

Gambar 16 Grafik Hasil Pengujian Parameter Downtime

Downtime adalah pengukuran waktu yang dibutuhkan untuk mengubah jalur jaringan dari jalur aktif ke jalur cadangan[9]. Hasil parameter downtime didapatkan dengan melakukan test ping dari client ke server dan pada waktu tertentu jalur kearah router spoke primary dimatikan. Beberapa saat hasil ping akan menunjukkan request time out dan terjadi downtime pada jaringan namun jaringan akan kembali pulih karena sudah ada metode redundansi pada router spoke. Parameter ini dibandingkan untuk melihat metode mana yang memiliki downtime seminimal mungkin. Rata-rata downtime yang terjadi pada jaringan dengan metode HSRP adalah 47,11 detik. Sedangkan rata-rata downtime yang terjadi pada jaringan dengan metode GLBP adalah 49,06 detik. Metode HSRP memiliki downtime lebih cepat 1,95 detik atau 4,13\% dari metode GLBP. Namun berdasarkan 10 kali pengujian yang sudah dilakukan, downtime dari metode GLBP pernah menyentuh angka tercepat yaitu 19,82 detik. Sehingga, HSRP memiliki nilai parameter downtime rata-rata yang lebih baik dari GLBP.

\section{KESIMPULAN}

Berdasarkan hasil implementasi metode HSRP atau GLBP pada router spoke, dapat diambil kesimpulan bahwa kedua metode tersebut dapat menjadi solusi redundansi spoke untuk meningkatkan ketersediaan jaringan. Hasil 
ISSN 2614-5278 (media cetak), ISSN 2548-8368 (media online)

Available Online at https://ejurnal.stmik-budidarma.ac.id/index.php/mib DOI 10.30865/mib.v5i2.2846

yang didapat dari pengujian download file sebesar 5MB dari client menggunakan layanan FTP sebanyak 10 kali adalah terdapat penurunan throughput serta kenaikan delay dan transfer time pada saat jalur kearah router spoke primary dimatikan. Penurunan throughput yang terjadi pada HSRP masih lebih kecil dibanding pada GLBP, dengan rata-rata selisih $1,05 \mathrm{Kbit} / \mathrm{s}$ atau $0,20 \%$. Kenaikan delay rata-rata pada HSRP lebih kecil dibanding pada GLBP dengan selisih 0,13 ms atau 1,07\%. Kenaikan waktu transfer data pada HSRP masih lebih kecil dibanding pada GLBP dengan selisih 1,06 detik atau 1,49\%. Metode HSRP memiliki downtime lebih cepat 1,95 detik atau 4,13\% dari metode GLBP. Berdasarkan hasil pengujian tersebut, Router spoke dengan metode HSRP mendapatkan nilai parameter yang lebih baik dibanding dengan metode GLBP. Sehingga didapatkan kesimpulan bahwa solusi redundansi yang sesuai pada router Spoke adalah metode HSRP.

\section{REFERENCES}

[1] N. Angelescu, D. C. Puchianu, G. Predusca, L. D. Circiumarescu, and G. Movila, "DMVPN simulation in GNS3 network simulation software," 2017, doi: 10.1109/ECAI.2017.8166444.

[2] S. U. Masruroh, K. H. P. Widya, A. Fiade, and I. R. Julia, "Performance Evaluation DMVPN Using Routing Protocol RIP, OSPF, and EIGRP," 2019, doi: 10.1109/CITSM.2018.8674051.

[3] F. Shahriar, S. Newaz, S. Z. Rashid, M. A. Rahman, and M. F. Rahman, "Designing a reliable and redundant network for multiple VLANs with Spanning Tree Protocol (STP) and Fast Hop Redundancy Protocol (FHRP)," 2018.

[4] I. G. M. S. B. Pracasitaram, N. P. Sastra, and N. D. Wirastuti, "Performansi Jaringan TCP/IP Menggunakan Metode VRRP, HSRP, dan GLBP," Maj. Ilm. Teknol. Elektro, 2019, doi: 10.24843/mite.2019.v18i01.p11.

[5] A. Akmaludin, A. Mt, S. U. Masruroh, and M. Sc, "Evalusi Kinerja Hot Standby Router Protocol (HSRP) dan Gateway Load Balancing Protocol (GLBP) untuk Layanan Video Streaming," CyberSecurity dan Forensik Digit., 2019.

[6] P. PRAMAWAHYUDI, R. SYAHPUTRA, and A. RIDWAN, "Evaluasi Kinerja First Hop Redundancy Protocols untuk Topologi Star di Routing EIGRP,” ELKOMIKA J. Tek. Energi Elektr. Tek. Telekomun. Tek. Elektron., 2020, doi: 10.26760/elkomika.v8i3.627.

[7] U. Anwar, J. Teng, H. A. Umair, and A. Sikander, "Performance analysis and functionality comparison of FHRP protocols," in 2019 IEEE 11th International Conference on Communication Software and Networks, ICCSN 2019, Jun. 2019, pp. 111-115, doi: 10.1109/ICCSN.2019.8905333.

[8] I. Nurhaida, D. W. P. Pratama, R. A. M. Zen, and H. Wei, "INTERIOR GATEWAY PROTOCOL ROUTING PERFORMANCE COMPARISON OF THE VIRTUAL PRIVATE NETWORK BASED ON MULTI PROTOCOL LABEL SWITCHING AND DIRECTLINK BACKUPSED ON MPLS AND DIRECT-LINK BACKUP," SINERGI, vol. 24, no. 1, p. 1, Dec. 2019, doi: 10.22441/sinergi.2020.1.001.

[9] I. Ristanti Julia, H. Bayu Suseno, L. Kesuma Wardhani, D. Khairani, K. Hulliyah, and A. Taufik Muharram, "Performance Evaluation of First Hop Redundancy Protocol (FHRP) on VRRP, HSRP, GLBP with Routing Protocol BGP and EIGRP," Oct. 2020, doi: 10.1109/CITSM50537.2020.9268799.

[10] M. I. DJOMI, R. MUNADI, and R. M. NEGARA, "Analisis Performansi Layanan FTP danVideo Streaming berbasis Network Function Virtualization menggunakan Docker Containers," ELKOMIKA J. Tek. Energi Elektr. Tek. Telekomun. Tek. Elektron., 2018, doi: 10.26760/elkomika.v6i2.180.

[11] T. Alam et al., "Design and Implementation of a Secured Enterprise Network using Dynamic Multipoint VPN with HSRP Protocol," 2018, doi: 10.1109/ICISET.2018.8745601.

[12] Cisco, "Cisco Dynamic Multipoint VPN: Simple and Secure Branch-to-Branch Communications," Cisco.com, p. 8, 2014, [Online]. Available: http://www.cisco.com/c/en/us/products/collateral/security/dynamic-multipoint-vpn-dmvpn/data_sheet_c78-468520.html.

[13] Cisco, "First Hop Redundancy Protocols Configuration Guide, Cisco IOS XE Release 3S - HSRP MD5 Authentication [Cisco IOS XE 3S]," Cisco, no. 6387, 2018, [Online]. Available: https://www.cisco.com/c/en/us/td/docs/ios-xml/ios/ipapp_fhrp/configuration/15$\mathrm{mt} / \mathrm{fhp}-15$-mt-book/fhp-hsrp-md5.html\%0Ahttps://www.cisco.com/c/en/us/td/docs/ios-xml/ios/ipapp_fhrp/configuration/xe-3s/fhp-xe3s-book/fhp-hsrp-md5.html

[14] Z. U. Rahman et al., "Performance Evaluation of First HOP Redundancy Protocols ( HSRP , VRRP \& GLBP )," J . Appl . Env. . Biol . Sci, 2017

[15] W. Purwanto and S. Risnanto, "IMPLEMENTASI METODE HSRP PADA BANK JAWA BARAT DAN BANTEN KANTOR WILAYAH I DAN KCP SIMPANG DAGO,” Infotronik J. Teknol. Inf. dan Elektron., 2018, doi: 10.32897/infotronik.2018.3.1.88.

[16] C. V. Ravikumar, Y. M. Srikanth, P. Sairam, M. Sundeep, K. P. Bagadi, and V. Annepu, "Performance analysis of HSRP in provisioning layer-3 gateway redundancy for corporate networks," Indian J. Sci. Technol., vol. 9, no. 20, pp. 2-6, 2016, doi: 10.17485/ijst/2016/v9i20/89851.

[17] H. D. Haryoyudhanto, I. Fitri, and A. Aningsih, "Implementasi Encapsulation Jaringan Redudansi VLAN Menggunakan Metode Hot Standby Router Protocol (HSRP)," JOINTECS (Journal Inf. Technol. Comput. Sci., 2020, doi: 10.31328/jointecs.v5i1.1247.

[18] S. J. X., J. P. S., and L. J. T., "JomNetwork: GLBP in Medium Size Enterprise," Int. J. Trend Sci. Res. Dev., vol. Volume-3, no. Issue2, pp. 725-728, 2019, doi: 10.31142/ijtsrd20285. 